\title{
ІНТЕЛЕКТУАЛЬНИЙ АЛГОРИТМ КЕРУВАННЯ ДЛЯ ЕНЕРГОЕФЕКТИВНОГО ВИРОЩУВАННЯ ЕНТОМОФАГІВ
}

\author{
Лисенко В.П. ${ }^{1}$, Чернова I.C. ${ }^{2}$ \\ ${ }^{1}$ Національний університет біоресурсів і природокористування України, ${ }^{2}$ Інженерно-технологічний інститут \\ «Біотехніка» НААН України \\ E-mail: ${ }^{1}$ lysenko@nubip.edu.ua, ${ }^{2}$ bioischernova@ukr.net \\ Copyright (C) 2018 by author and the journal "Automation technologies and business - processes. \\ This work is licensed under the Creative Commons Attribution International License (CC BY). \\ http://creativecommons.org/licanses/by/4.0
}

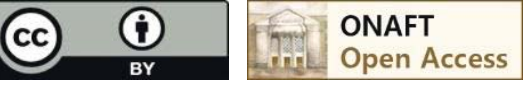

DOI: $10.15673 /$ atbp.v10i1.874

Анотація: Стаття присвячена енергоефективному вирошуванню ентомофагів. Об'єктом дослідження були процеси керування лабораторним виробництвом млинової вогнівки (Ерhestia kuеhniella), комахи-хазяїна ентомофага бракон (Habrobracon hebetor).

Метою досліджень є розроблення методу, а на його основі - алгоритму керування для енергоефективного вирощування ентомофагів із використанням теорії нечіткої логіки.

Розроблено метод енергоефективного вирощування ентомофагів, який на основі інформації про залежність прибутку виробництва від параметрів техноченозу (температури та відносної вологості повітря боксу для розведення комах), загальних витрат поживного середовища та витрат на інокуляцію поживного середовища яйчями комахи-хазяїна, витрат електроенергії, доходу, із використанням теорії нечіткої логіки дозволяє формувати стратегї керування електротехнічним комплексом для максимізації прибутку виробництва ентомофагів в умовах невизначеності.

Методи досліджень - експериментальний, аналітичний, нечіткого висновку.

За результатами експериментальних досліджень, проведених в Інженерно-технологічному інституті «Біотехніка», розроблено експертні системи нечіткого висновку для оцінки прибутку виробництва ентомокультур, створено бази знань та отримано поверхні нечіткого висновку, щзо дають можливість визначати такі параметри процесу вирощування ентомокультур з урахуванням збурення в умовах неповної вхідної інформації, за яких прибуток буде досягати максимального значення за умови мінімізації енерговитрат.

Abstract: The article is devoted to energyefficient of entomophages cultivation. The object of the study were the processes of control of the laboratory production of Ephestia kuehniella, the insect host of the entomophage Habrobracon hebetor.

The aim of the research is to develop a method, and on its basis, an algorithm for the energyefficient control of the cultivation of entomophages using fuzzy logic theory.

A method for energy efficient of entomophages cultivation was developed, which, based on information on the dependence of production profit on the parameters of technocenosis (temperature and relative humidity of the box air for insect breeding), the total expenditure of the nutrient medium and the costs of inoculating the nutrient medium with the eggs of the host insect, the costs of electricity, income, using the theory of fuzzy logic allows to formulate strategies for managing the electrotechnical complex for maximizing the profit of production of entomophages under conditions of uncertainty.

Research methods - experimental, analytical, fuzzy inference.

Based on the results of experimental studies conducted at the Biotechnica Engineering and Technology Institute, expert systems of fuzzy inference were developed to estimate the profit of production of entomocultures, knowledge bases were created and fuzzy inference surfaces were obtained, which make it possible to determine such parameters of the process of growing entomocultures with allowance for disturbances in the conditions of incomplete input information, at which the profit will reach the maximum value under the condition of minimizing energy costs.

Ключові слова: виробництво ентомофагів, метод, енергоефективне керування, нечітка логіка.

Key words: production of entomophages, method, energyefficient management, fuzzy logic.

Актуальність. Керування виробництвом ентомофагів потребує визначення такого методу, який дозволив би підвищити його енергетичну ефективність. Набір показників енергоефективності містить показники, що відбивають 
ступінь ефективності використання окремих видів ресурсів: продуктивності праці, фондовіддачі, матеріалоємності та енергоємності виробництва [1]. Інноваційним фактором, що впливає на енергоефективність, $є$ застосування енергозберігаючих технологій і обладнання [2]. В умовах економічної самостійності підприємств основним критерієм оцінки економічної ефективності енергозберігаючих заходів $є$ прибуток, що залишається у розпорядженні підприємства [3].

Аналіз останніх досліджень та публікацій. На сьогодні енергоефективне керування складними біотехнічними об'єктами реалізується за допомогою інтелектуальних систем $[4,5,6,7]$, перевагами яких на відміну від традиційних систем керування є врахування збурень, формалізація слабко-структурованих процесів та ідентифікація об'єкта в умовах невизначеності.

Мета дослідження - розроблення методу, а на його основі - алгоритму керування для енергоефективного вирощування ентомофагів із використанням теорії нечіткої логіки.

Матеріали і методи дослідження. Об’єкт дослідження - процеси керування лабораторним виробництвом млинової вогнівки (Ephestia kuehniella), комахи-хазяїна ентомофага бракон (Habrobracon hebetor). У роботі були використані результати експериментальних досліджень, проведених в Інженерно-технологічному інституті «Біотехніка» НААН України. Методи досліджень - експериментальний, аналітичний, нечіткого висновку.

Результати дослідження та їх обговорення. Процеси виробництва ентомофагів можуть бути представленими на трьох стратах: фізичні процеси розвитку ентомокультур по стадіям онтогенезу, керування якістю ентомопродукції й обробка інформації, економіка виробництва 3 точки зору його прибутку [8]. Пропонується підвищення енергоефективності виробництва ентомофага за рахунок такого методу керування, який поєднує оцінку: абіотичних параметрів постадійного розвитку ентомокультур; енергетичних витрат, пов'язаних із забезпеченням необхідних абіотичних параметрів в умовах збурення; доходу, який залежить від кількості та якості ентомологічної продукції; прибутку. Прибуток П(t) виробництва гусениць млинової вогнівки для напрацьовування ентомофага бракон визначається низкою параметрів та формалізований у вигляді кортежу:

$$
\begin{gathered}
\Pi(t)=<\theta, \varphi, V, P, \theta 1, D(t), E(t)>, \\
\Pi(t)=D(t)-E(t)-V-P, \\
D(t)=k(t) \cdot Я(t) \cdot N \cdot w_{k}, \\
E(t)=e \cdot w_{e}, \\
V=n \cdot N \cdot w_{n}, \\
P=\rho \cdot N \cdot w_{\rho},
\end{gathered}
$$

де $\theta$ - температура боксу для розведення комах, ${ }^{\circ} \mathrm{C} ; \varphi$ - відносна вологість боксу, \%; V - загальні витрати поживного середовища (меленого зерна ячменю), грн.; Р - загальні витрати на інокуляцію зерна яйцями млинової вогнівки, грн.; $\theta 1$ - температура навколишнього середовища, ${ }^{\circ} \mathrm{C} ; \mathrm{D}(\mathrm{t})$ - дохід від реалізації ентомопродукції, грн.; Е(t) - загальні витрати електроенергії на забезпечення заданих температури та відносної вологості повітря боксу, грн.; k(t) - кількість гусениць млинової вогнівки старшого віку, шт./кювету; Я(t) - якість ентомокультур за середньою масою гусениць старшого віку, г; N - кількість кювет, шт.; $\mathrm{w}_{\mathrm{k}}$ - вартість 1 кг гусениць, грн.; е - витрати електроенергії, кВт·год; $\mathrm{w}_{\mathrm{e}}$ вартість 1 кВт·год, грн.; n - кількість поживного середовища, кг/кювету; $\mathrm{w}_{\mathrm{n}}$ - вартість 1 кг зерна, грн.; $\rho$ - кількість яєць млинової вогнівки, внесених в зерно, г яєць/кювету; $\mathrm{w}_{\rho}$ - вартість 1 г яєць, грн.; $\mathrm{t}$ - тривалість циклу вирощування гусениць, діб.

Необхідним є визначення таких параметрів $(\theta, \varphi, \mathrm{V}, \mathrm{P}, \mathrm{D}(\mathrm{t}))$ процесу вирощування ентомокультур, за якими $\Pi(t) \rightarrow \max$ за умови $E(t) \rightarrow \min$.

Практична реалізація запропонованого методу керування виробництвом ентомофагів можлива за допомогою експертних систем нечіткого висновку типу Мамдані для оцінки прибутку виробництва ентомокультур (рис. 1) на базі пакету розширення Fuzzy Logic Toolbox for MATLAB (рис. 2).

В табл. 1 наведено результати експериментальних досліджень.

В табл. 2 наведено дані для створення продукційних правил баз знань SNV1. 


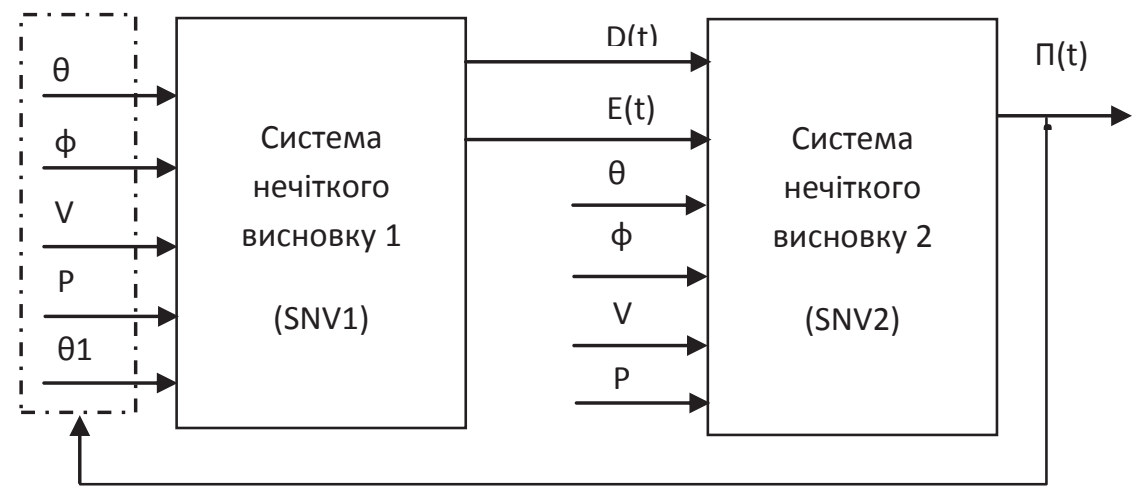

Рис. 1 - Експертні системи нечіткого висновку для оцінки прибутку виробництва ентомокультур
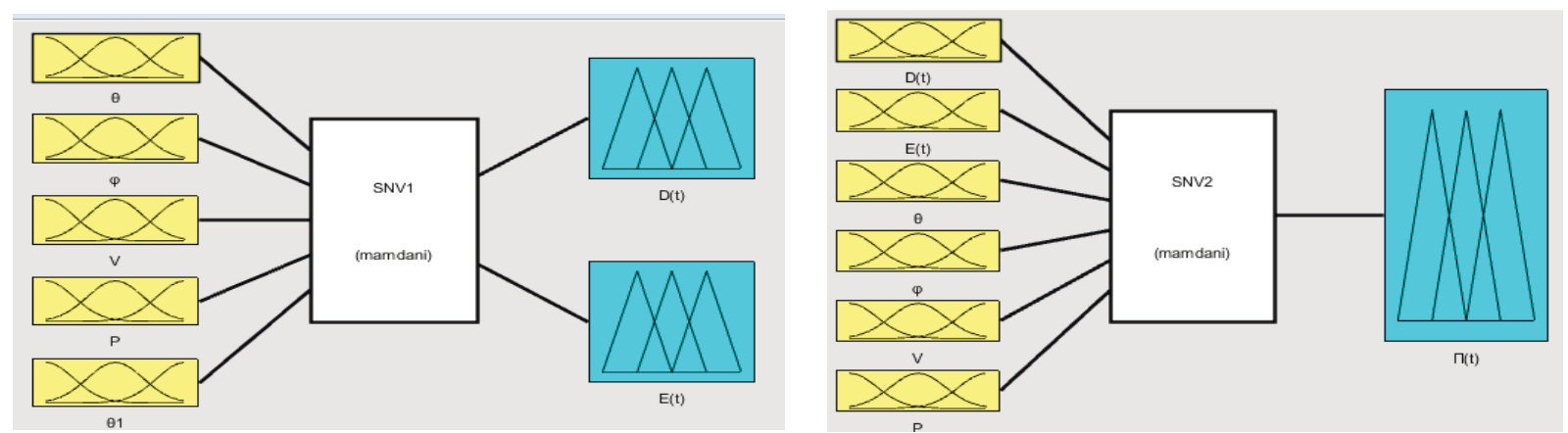

Рис. 2. Функціональні схеми експертних систем в середовищі MATLAB

1. Результати експериментальних досліджень

\begin{tabular}{|l|l|l|l|l|l|}
\hline$\theta,{ }^{\circ} \mathrm{C}$ & 26,8 & 26,8 & 28 & 26,8 & 28 \\
\hline$\varphi, \%$ & 70 & 70 & 50 & 70 & 50 \\
\hline n, кг/кювету & 1 & 2 & 1 & 1 & 1 \\
\hline N, шт. & 60 & 60 & 60 & 60 & 60 \\
\hline $\mathrm{w}_{\mathrm{n}}$, грн./ 1кг & 7 & 7 & 7 & 7 & 7 \\
\hline$\rho$, гккювету & 0,2 & 0,2 & 0,2 & 0,2 & 0,4 \\
\hline $\mathrm{w}_{\rho}$, грн. /1 г & 71,85 & 71,85 & 71,85 & 71,85 & 71,85 \\
\hline $\mathrm{V}$, грн. & 420 & 840 & 420 & 420 & 420 \\
\hline Р, грн. & 862,2 & 862,2 & 862,2 & 862,2 & 1724,4 \\
\hline$\theta 1,{ }^{\circ} \mathrm{C}$ & 23 & 23 & 21 & 8 & 21 \\
\hline $\mathrm{k}(\mathrm{t})$, шт./кювету & 7220 & 6900 & 6192 & 8560 & 8980 \\
\hline Я(t), г & 0,028 & 0,027 & 0,024 & 0,026 & 0,021 \\
\hline $\mathrm{w}_{\mathrm{k}}$, грн. / 1г гусениць & 0,219 & 0,219 & 0,219 & 0,219 & 0,219 \\
\hline $\mathrm{D}(\mathrm{t})$, грн. & 2656,38 & 2447,98 & 1952,71 & 2924,44 & 2477,94 \\
\hline $\mathrm{e}$, кВт·год & 78 & 78 & 85 & 120 & 85 \\
\hline $\mathrm{w}_{\mathrm{e}}$, грн. / 1 кВт· год & 1,68 & 1,68 & 1,68 & 1,68 & 1,68 \\
\hline Е(t), грн. & 131,04 & 131,04 & 142,8 & 201,6 & 142,8 \\
\hline П(t), грн. & 1243,14 & 614,74 & 527,71 & 1440,64 & 190,74 \\
\hline $\mathrm{t}$, діб & 30 & 30 & 30 & 30 & 30 \\
\hline
\end{tabular}




\section{2. Дані для створення продукційних правил бази знань SNV1}

\begin{tabular}{|c|c|c|c|c|}
\hline Змінні & $\begin{array}{l}\text { Діапазон } \\
\text { зміню- } \\
\text { вання } \\
\end{array}$ & $\begin{array}{l}\text { Терм- } \\
\text { множи- } \\
\text { ни } \\
\end{array}$ & Лінгвістична оцінка & $\begin{array}{l}\text { Тип і параметри } \\
\text { функцій } \\
\text { приналежності }\end{array}$ \\
\hline \multirow[t]{2}{*}{$\theta,{ }^{\circ} \mathrm{C}$} & \multirow[t]{2}{*}{$26,8-28$} & $\theta \mathrm{n}$ & Нижня межа температури повітря боксу & $\begin{array}{l}\text { Gaussmf } \quad[0,2039 ; \\
26,8]\end{array}$ \\
\hline & & $\theta \mathrm{v}$ & Верхня межа температури повітря боксу & Gaussmf $[0,2038 ; 28]$ \\
\hline \multirow[t]{2}{*}{$\varphi, \%$} & \multirow[t]{2}{*}{$50-70$} & $\varphi 1$ & Нижня межа відносної вологості повітря боксу & Gaussmf $[3,398 ; 50]$ \\
\hline & & $\varphi 2$ & Верхня межа відносної вологості повітря боксу & Gaussmf [3,398; 70] \\
\hline \multirow[t]{2}{*}{ V, грн. } & \multirow[t]{2}{*}{$420-840$} & V1 & $\begin{array}{l}\text { Нижня межа загальних витрат поживного середовища } \\
\text { (зерна) }\end{array}$ & Gaussmf $[71,34 ; 420]$ \\
\hline & & V2 & $\begin{array}{l}\text { Верхня межа загальних витрат поживного середовища } \\
\text { (зерна) }\end{array}$ & Gaussmf $[71,34 ; 840]$ \\
\hline \multirow[t]{2}{*}{ Р, грн. } & \multirow[t]{2}{*}{$\begin{array}{l}862,2- \\
1724,4\end{array}$} & P1 & Нижня межа загальних витрат на інокуляцію зерна & $\begin{array}{l}\text { Gaussmf } \\
862,2]\end{array}$ \\
\hline & & $\mathrm{P} 2$ & Верхня межа загальних витрат на інокуляцію зерна & $\begin{array}{l}\text { Gaussmf } \\
1724]\end{array}$ \\
\hline \multirow[t]{2}{*}{$\theta 1,{ }^{\circ} \mathrm{C}$} & \multirow[t]{2}{*}{$8-23$} & $\theta 11$ & Нижня межа температури навколишнього середовища & Gaussmf [2,548; 8] \\
\hline & & $\theta 12$ & Верхня межа температури навколишнього середовища & Gaussmf [2,548; 23] \\
\hline \multirow[t]{3}{*}{$\begin{array}{l}\mathrm{D}(\mathrm{t}), \\
\text { грн. }\end{array}$} & \multirow[t]{3}{*}{$\begin{array}{l}1952,71- \\
2924,44\end{array}$} & $\mathrm{D} 1(\mathrm{t})$ & Нижня межа доходу & $\begin{array}{l}\text { Gaussmf } \\
1953]\end{array}$ \\
\hline & & $\mathrm{D} 2(\mathrm{t})$ & Середня межа доходу & $\begin{array}{l}\text { Gaussmf } \\
\text { 2656] }\end{array}$ \\
\hline & & D3(t) & Верхня межа доходу & $\begin{array}{l}\text { Gaussmf } \\
\text { 2924] }\end{array}$ \\
\hline \multirow{3}{*}{$\begin{array}{l}\mathrm{E}(\mathrm{t}), \\
\text { грн. }\end{array}$} & \multirow[t]{3}{*}{$131-202$} & E1(t) & Нижня межа загальних витрат електроенергії & Gaussmf $[12,06 ; 131]$ \\
\hline & & $\mathrm{E} 2(\mathrm{t})$ & Середня межа загальних витрат електроенергії & Gaussmf $[12,06 ; 143]$ \\
\hline & & E3(t) & Верхня межа загальних витрат електроенергії & Gaussmf [12,06; 202] \\
\hline
\end{tabular}

На рис. 3 представлено базу знань SNV1. Продукційні правила бази знань сформовано таким чином:

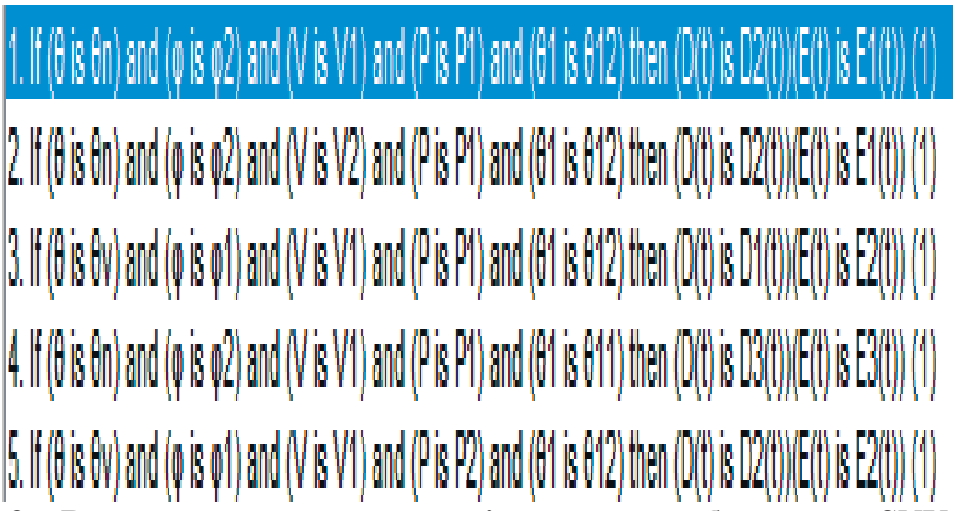

Рис. 3 - Вигляд редактора продукційних правил бази знань SNV1

1: якщо $\theta$ є «Нижня межа температури повітря боксу» і $\varphi$ є «Верхня межа відносної вологості повітря боксу» $\mathrm{i}$ V $\mathrm{\epsilon}$ «Нижня межа загальних витрат поживного середовища (зерна)» і Р є «Нижня межа загальних витрат на інокуляцію зерна» i $\theta 1 \epsilon$ «Верхня межа температури навколишнього середовища», то $\mathrm{D}(\mathrm{t}) \epsilon$ «Середня межа доходу» $\mathrm{i} \mathrm{E}(\mathrm{t}) \epsilon$ «Нижня межа загальних витрат електроенергії»;

2: якщо $\theta \epsilon$ «Нижня межа температури повітря боксу» і $\varphi €$ «Верхня межа відносної вологості повітря боксу» $\mathrm{i}$ V $\epsilon$ «Верхня межа загальних витрат поживного середовища (зерна)» і Р є «Нижня межа загальних витрат на інокуляцію зерна» і $\theta 1 \epsilon$ «Верхня межа температури навколишнього середовища», то $\mathrm{D}(\mathrm{t}) \epsilon$ «Середня межа доходу» $\mathrm{i} \mathrm{E}(\mathrm{t}) \epsilon$ «Нижня межа загальних витрат електроенергії»;

3: якщо $\theta \epsilon$ «Верхня межа температури повітря боксу» і $\varphi €$ «Нижня межа відносної вологості повітря боксу» $\mathrm{i}$ V $\epsilon$ «Нижня межа загальних витрат поживного середовища (зерна)» і P є «Нижня межа загальних витрат на інокуляцію зерна» i $\theta 1 \epsilon$ «Верхня межа температури навколишнього середовища», то $\mathrm{D}(\mathrm{t}) \epsilon$ «Нижня межа доходу» $\mathrm{i} \mathrm{E}(\mathrm{t}) \epsilon$ «Середня межа загальних витрат електроенергії»;

4: якщо $\theta \epsilon$ «Нижня межа температури повітря боксу» і $\varphi$ є «Верхня межа відносної вологості повітря боксу» $\mathrm{i}$ V $\epsilon$ 
«Нижня межа загальних витрат поживного середовища (зерна)» і Р є «Нижня межа загальних витрат на інокуляцію зерна» i $\theta 1 \epsilon$ «Нижня межа температури навколишнього середовища», то $\mathrm{D}(\mathrm{t}) \mathrm{\epsilon}$ «Верхня межа доходу» $\mathrm{i}(\mathrm{t}) \epsilon$ «Верхня межа загальних витрат електроенергії»;

5: якщо $\theta \epsilon$ «Верхня межа температури повітря боксу» і $\varphi €$ «Нижня межа відносної вологості повітря боксу» $\mathrm{i}$ V $\epsilon$ «Нижня межа загальних витрат поживного середовища (зерна)» і $\mathrm{P} \epsilon$ «Верхня межа загальних витрат на інокуляцію зерна» і $\theta 1 \epsilon$ «Верхня межа температури навколишнього середовища», то $\mathrm{D}(\mathrm{t}) \epsilon$ «Середня межа доходу» $\mathrm{i}(\mathrm{t}) \epsilon$ «Середня межа загальних витрат електроенергії».

За результатами нечіткого висновку SNV1 визначено, що за $\theta=26,8{ }^{\circ} \mathrm{C}, \varphi=70 \%, \mathrm{~V}=500$ грн., $\mathrm{P}=1020$ грн., $\theta 1=(20-23)$ ${ }^{\circ} \mathrm{C}$ дохід $\mathrm{D}(\mathrm{t})$ становить 2630 грн. та загальні витрати електроенергії $\mathrm{E}(\mathrm{t})=142$ грн. (рис. 4, рис. 5). Середня похибка апроксимації за $\mathrm{D}(\mathrm{t})$ склала 5,26 \%, за $\mathrm{E}(\mathrm{t})-4,76$ \%, що знаходиться в межі допустимих значень [9].

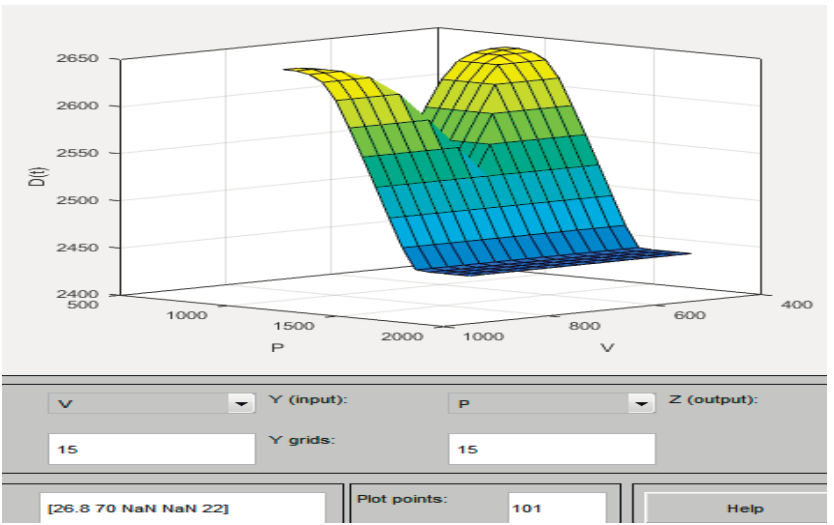

Рис. 4 - Залежність доходу від загальних витрат поживного середовища та загальних витрат на інокуляцію зерна

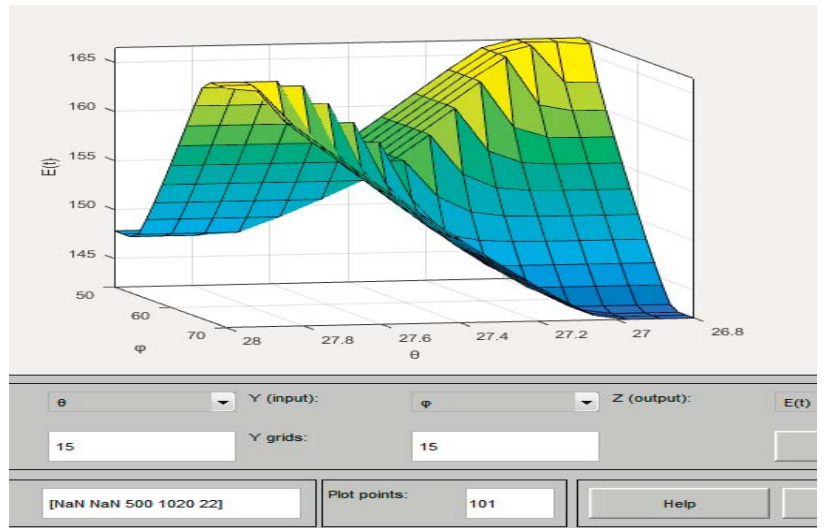

Рис. 5 - Залежність загальних витрат електроенергії від температури та відносної вологості повітря боксу

В табл. 3 наведено дані для створення продукційних правил баз знань SNV2.

\section{3. Дані для створення продукційних правил бази знань SNV2}

\begin{tabular}{|c|c|c|c|c|}
\hline Змінні & $\begin{array}{l}\text { Діапазон } \\
\text { зміню- } \\
\text { вання } \\
\end{array}$ & $\begin{array}{l}\text { Терм- } \\
\text { множини }\end{array}$ & Лінгвістична оцінка & $\begin{array}{l}\text { Тип і параметри } \\
\text { функцій } \\
\text { приналежності }\end{array}$ \\
\hline \multirow{3}{*}{$\begin{array}{l}\mathrm{D}(\mathrm{t}) \\
\text { грн. }\end{array}$} & \multirow{3}{*}{$\begin{array}{l}1952,71- \\
2924,44\end{array}$} & $\mathrm{D} 1(\mathrm{t})$ & Нижня межа доходу & Gaussmf [165,1; 1953] \\
\hline & & $\mathrm{D} 2(\mathrm{t})$ & Середня межа доходу & Gaussmf [165,1; 2656] \\
\hline & & D3(t) & Верхня межа доходу & Gaussmf [165,1; 2924] \\
\hline \multirow{3}{*}{$\begin{array}{l}\mathrm{E}(\mathrm{t}) \\
\text { грн. }\end{array}$} & \multirow[t]{3}{*}{$131-202$} & E1(t) & Нижня межа загальних витрат електроенергії & Gaussmf $[12,06 ; 131]$ \\
\hline & & $\mathrm{E} 2(\mathrm{t})$ & Середня межа загальних витрат електроенергії & Gaussmf $[12,06 ; 143]$ \\
\hline & & E3(t) & Верхня межа загальних витрат електроенергії & Gaussmf $[12,06 ; 202]$ \\
\hline \multirow[t]{2}{*}{$\theta,{ }^{\circ} \mathrm{C}$} & \multirow[t]{2}{*}{$26,8-28$} & $\theta \mathrm{n}$ & Нижня межа температури повітря боксу & Gaussmf [0,2039; 26,8] \\
\hline & & $\theta \mathrm{v}$ & Верхня межа температури повітря боксу & Gaussmf $[0,2038 ; 28]$ \\
\hline \multirow[t]{2}{*}{$\varphi, \%$} & \multirow[t]{2}{*}{$50-70$} & $\varphi 1$ & Нижня межа відносної вологості повітря боксу & Gaussmf $[3,398 ; 50]$ \\
\hline & & $\varphi 2$ & Верхня межа відносної вологості повітря боксу & Gaussmf $[3,398 ; 70]$ \\
\hline \multirow[t]{2}{*}{ V, грн. } & \multirow[t]{2}{*}{$420-840$} & V1 & $\begin{array}{l}\text { Нижня межа загальних } \\
\text { середовища (зерна) }\end{array}$ & Gaussmf $[71,34 ; 420]$ \\
\hline & & $\mathrm{V} 2$ & $\begin{array}{l}\text { Верхня межа загальних витрат поживного } \\
\text { середовища (зерна) }\end{array}$ & Gaussmf $[71,34 ; 840]$ \\
\hline \multirow[t]{2}{*}{ Р, грн. } & \multirow[t]{2}{*}{$\begin{array}{l}862,2- \\
1724,4\end{array}$} & P1 & $\begin{array}{l}\text { Нижня межа загальних витрат внесених в зерно } \\
\text { яєць }\end{array}$ & Gaussmf [146,5; 862,2] \\
\hline & & $\mathrm{P} 2$ & $\begin{array}{l}\text { Верхня межа загальних витрат внесених в зерно } \\
\text { яєць }\end{array}$ & Gaussmf [146,5; 1724] \\
\hline \multirow{3}{*}{$\begin{array}{l}\Pi(\mathrm{t}) \\
\text { грн. }\end{array}$} & \multirow{3}{*}{$\begin{array}{l}190,74- \\
1440,64\end{array}$} & $\Pi 1(\mathrm{t})$ & Нижня межа прибутку & Gaussmf $[5 ; 190,7]$ \\
\hline & & $\Pi 2(\mathrm{t})$ & Середня межа прибутку & Gaussmf [5; 614,7] \\
\hline & & $\Pi 3(\mathrm{t})$ & Верхня межа прибутку & Gaussmf [5; 1441] \\
\hline
\end{tabular}

На рис. 6 наведена база знань SNV2. Продукційні правила бази знань SNV2 сформовано таким чином: 


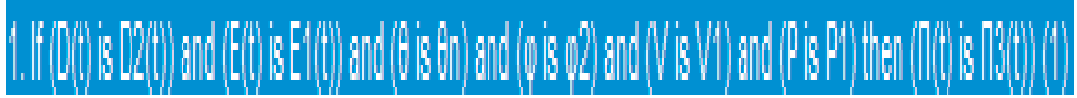

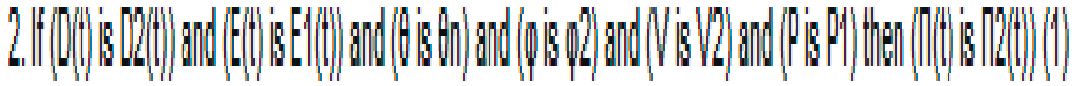
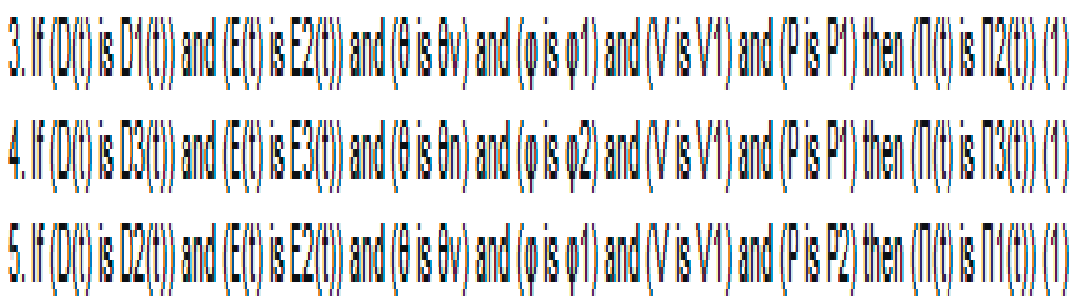

Рис. 6 - Вигляд редактора продукційних правил бази знань SNV2

1: якщо $\mathrm{D}(\mathrm{t}) \epsilon$ «Середня межа доходу» $\mathrm{i} \mathrm{E}(\mathrm{t}) \epsilon$ «Нижня межа загальних витрат електроенергії» і $\theta \epsilon$ «Нижня межа температури повітря боксу» і $\varphi €$ «Верхня межа відносної вологості повітря боксу» $\mathrm{i} \mathrm{V} \epsilon$ «Нижня межа загальних витрат поживного середовища (зерна)» і Р є «Нижня межа загальних витрат на інокуляцію зерна», то П(t) $є$ «Верхня межа прибутку»;

2: якщо $\mathrm{D}(\mathrm{t}) \epsilon$ «Середня межа доходу» $\mathrm{i} \mathrm{E}(\mathrm{t}) \epsilon$ «Нижня межа загальних витрат електроенергії» $\mathrm{i} \theta \epsilon$ «Нижня межа температури повітря боксу» і $\varphi є$ «Верхня межа відносної вологості повітря боксу» і V є «Верхня межа загальних витрат поживного середовища (зерна)» і Р $\epsilon$ «Нижня межа загальних витрат на інокуляцію зерна», то П(t) $є$ «Середня межа прибутку»;

3: якщо $\mathrm{D}(\mathrm{t}) \epsilon$ «Нижня межа доходу» $\mathrm{i} \mathrm{E}(\mathrm{t}) \epsilon$ «Середня межа загальних витрат електроенергії» $\mathrm{i} \theta \epsilon$ «Верхня межа температури повітря боксу» і $\varphi$ є «Нижня межа відносної вологості повітря боксу» $\mathrm{i}$ V є «Нижня межа загальних витрат поживного середовища (зерна)» і Р $\epsilon$ «Нижня межа загальних витрат на інокуляцію зерна», то П(t) $\epsilon$ «Середня межа прибутку»;

4: якщо $\mathrm{D}(\mathrm{t}) \epsilon$ «Верхня межа доходу» $\mathrm{i} \mathrm{E}(\mathrm{t}) \epsilon$ «Верхня межа загальних витрат електроенергії» і $\theta \epsilon$ «Нижня межа температури повітря боксу» і $\varphi$ є «Верхня межа відносної вологості повітря боксу» $\mathrm{V}$ V є «Нижня межа загальних витрат поживного середовища (зерна)» і Р є «Нижня межа загальних витрат на інокуляцію зерна», то П(t) є «Верхня межа прибутку»;

5: якщо $\mathrm{D}(\mathrm{t}) \epsilon$ «Середня межа доходу» $\mathrm{i} \mathrm{E}(\mathrm{t}) \epsilon$ «Середня межа загальних витрат електроенергії» і $\theta \epsilon$ «Верхня межа температури повітря боксу» і $\varphi$ є «Нижня межа відносної вологості повітря боксу» $\mathrm{i} \mathrm{V} \epsilon$ «Нижня межа загальних витрат поживного середовища (зерна)» і Р є «Верхня межа загальних витрат на інокуляцію зерна», то П(t) є «Нижня межа прибутку».

За результатом нечіткого висновку SNV2 встановлено, що $\mathrm{D}(\mathrm{t})=(2254-2924)$ грн., $\mathrm{E}(\mathrm{t})=131$ грн., $\theta=26,8^{\circ} \mathrm{C}, \varphi=70 \%$, $\mathrm{V}=500$ грн., $\mathrm{P}=1020$ грн., прибуток П(t) буде максимальним - 1440 грн. за умови мінімізації енерговитрат (рис. 7, рис. 8). Середня похибка апроксимації за П(t) склала 6,62 \% (в межі допустимих значень [9]).

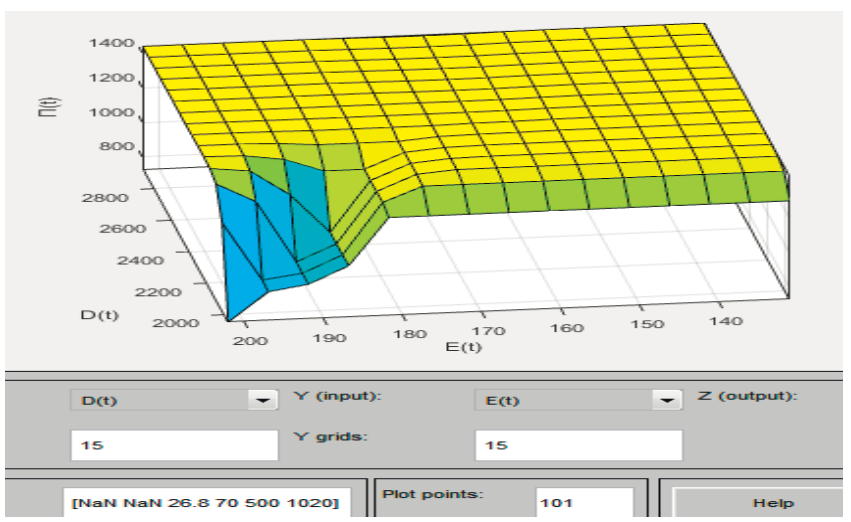

Рис. 7 - Залежність прибутку від доходу та загальних витрат електроенергії

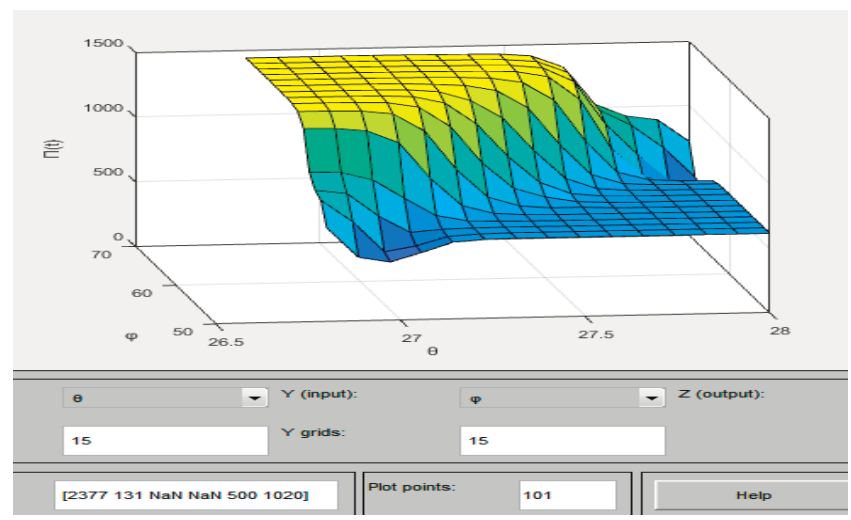

Рис. 8 - Залежність прибутку від температури та відносної вологості повітря боксу 
Математичний опис знаходження прибутку передбачає визначення чітких значень П(t) $)_{0}$, використовуючи при цьому базу знань (рис. 6) і чіткі значення $\mathrm{D}(\mathrm{t})_{0}, \mathrm{E}(\mathrm{t})_{0}, \theta_{0}, \varphi_{0}, \mathrm{~V}_{0}, \mathrm{P}_{0}$. Він складається з наступних дій [10]:

1. Визначення ступеню істинності для передумов кожного правила: $\mathrm{D} 1(\mathrm{t})\left(\mathrm{D}(\mathrm{t})_{0}\right), \mathrm{D} 2(\mathrm{t})\left(\mathrm{D}(\mathrm{t})_{0}\right), \mathrm{D} 3(\mathrm{t})\left(\mathrm{D}(\mathrm{t})_{0}\right)$, $\mathrm{E} 1(\mathrm{t})\left(\mathrm{E}(\mathrm{t})_{0}\right), \mathrm{E} 2(\mathrm{t})\left(\mathrm{E}(\mathrm{t})_{0}\right), \mathrm{E} 3(\mathrm{t})\left(\mathrm{E}(\mathrm{t})_{0}\right), \theta \mathrm{n}\left(\theta_{0}\right), \theta \mathrm{v}\left(\theta_{0}\right), \varphi 1\left(\varphi_{0}\right), \varphi 2\left(\varphi_{0}\right), \mathrm{V} 1\left(\mathrm{~V}_{0}\right), \mathrm{V} 2\left(\mathrm{~V}_{0}\right), \mathrm{P} 1\left(\mathrm{P}_{0}\right), \mathrm{P} 2\left(\mathrm{P}_{0}\right)$.

2. Знаходження рівнів відсікання для передумов кожного з правил (із використанням операції логічного мінімуму):

$$
\begin{aligned}
& \alpha_{1}=D 2(t)\left(D(t)_{0}\right) \wedge E 1(t)\left(E(t)_{0}\right) \wedge \theta n\left(\theta_{0}\right) \wedge \varphi 2\left(\varphi_{0}\right) \wedge V 1\left(V_{0}\right) \wedge P 1\left(P_{0}\right), \\
& \alpha_{2}=D 2(t)\left(D(t)_{0}\right) \wedge E 1(t)\left(E(t)_{0}\right) \wedge \theta n\left(\theta_{0}\right) \wedge \varphi 2\left(\varphi_{0}\right) \wedge V 2\left(V_{0}\right) \wedge P 1\left(P_{0}\right), \\
& \alpha_{3}=D 1(t)\left(D(t)_{0}\right) \wedge E 2(t)\left(E(t)_{0}\right) \wedge \theta v\left(\theta_{0}\right) \wedge \varphi 1\left(\varphi_{0}\right) \wedge V 1\left(V_{0}\right) \wedge P 1\left(P_{0}\right), \\
& \alpha_{4}=D 3(t)\left(D(t)_{0}\right) \wedge E 3(t)\left(E(t)_{0}\right) \wedge \theta n\left(\theta_{0}\right) \wedge \varphi 2\left(\varphi_{0}\right) \wedge V 1\left(V_{0}\right) \wedge P 1\left(P_{0}\right), \\
& \alpha_{5}=D 2(t)\left(D(t)_{0}\right) \wedge E 2(t)\left(E(t)_{0}\right) \wedge \theta\left(\theta_{0}\right) \wedge \varphi 1\left(\varphi_{0}\right) \wedge V 1\left(V_{0}\right) \wedge P 2\left(P_{0}\right) .
\end{aligned}
$$

3. Знаходження усічених функції приналежності:

$$
\begin{aligned}
& \Pi 3(t)^{\prime}(\Pi(t))=\left(\alpha_{1} \wedge \Pi 3(t)(\Pi(t)),\right. \\
& \Pi 2(t)^{\prime}(\Pi(t))=\left(\alpha_{2} \wedge \Pi 2(t)(\Pi(t)),\right. \\
& \Pi 2(t)^{\prime}(\Pi(t))=\left(\alpha_{3} \wedge \Pi 2(t)(\Pi(t)),\right. \\
& \Pi 3(t)^{\prime}(\Pi(t))=\left(\alpha_{4} \wedge \Pi 3(t)(\Pi(t)),\right. \\
& \Pi 1(t)^{\prime}(\Pi(t))=\left(\alpha_{5} \wedge \Pi 1(t)(\Pi(t)) .\right.
\end{aligned}
$$

4. Об'єднання усічених функцій із використанням операції логічного максимуму:

$$
\begin{aligned}
& \mu_{\Sigma}(\Pi(t))=\left(\alpha _ { 1 } \wedge \Pi 3 ( t ) ( \Pi ( t ) ) \vee \left(\alpha _ { 2 } \wedge \Pi 2 ( t ) ( \Pi ( t ) ) \vee \left(\alpha_{3} \wedge \Pi 2(t)(\Pi(t)) \vee\right.\right.\right. \\
& \vee\left(\alpha _ { 4 } \wedge \Pi 3 ( t ) ( \Pi ( t ) ) \vee \left(\alpha_{5} \wedge \Pi 1(t)(\Pi(t)) .\right.\right.
\end{aligned}
$$

5. Приведення до чіткості центроїдним методом:

$$
\Pi(t)_{0}=\frac{\int_{\Omega} \Pi(t) \mu_{\Sigma}(\Pi(t)) d \Pi(t)}{\int_{\Omega} \mu_{\Sigma}(\Pi(t)) d \Pi(t)} .
$$

При цьому визначення чітких значень $\mathrm{D}(\mathrm{t})_{0}, \mathrm{E}(\mathrm{t})_{0}$ проводилось шляхом використання бази знань (рис. 3) та чітких значень $\theta_{0}, \varphi_{0}, \mathrm{~V}_{0}, \mathrm{P}_{0}, \theta 1_{0}$ :

$$
\begin{aligned}
& \beta_{1}=\theta n\left(\theta_{0}\right) \wedge \varphi 2\left(\varphi_{0}\right) \wedge V 1\left(V_{0}\right) \wedge P 1\left(P_{0}\right) \wedge \theta 12\left(\theta 1_{0}\right), \\
& \beta_{2}=\theta n\left(\theta_{0}\right) \wedge \varphi 2\left(\varphi_{0}\right) \wedge V 2\left(V_{0}\right) \wedge P 1\left(P_{0}\right) \wedge \theta 12\left(\theta 1_{0}\right), \\
& \beta_{3}=\theta \wedge\left(\theta_{0}\right) \wedge \varphi 1\left(\varphi_{0}\right) \wedge V 1\left(V_{0}\right) \wedge P 1\left(P_{0}\right) \wedge \theta 12\left(\theta 1_{0}\right), \\
& \beta_{4}=\theta n\left(\theta_{0}\right) \wedge \varphi 2\left(\varphi_{0}\right) \wedge V 1\left(V_{0}\right) \wedge P 1\left(P_{0}\right) \wedge \theta 11\left(\theta 1_{0}\right), \\
& \beta_{5}=\theta v\left(\theta_{0}\right) \wedge \varphi 1\left(\varphi_{0}\right) \wedge V 1\left(V_{0}\right) \wedge P 2\left(P_{0}\right) \wedge \theta 12\left(\theta 1_{0}\right), \\
& D 2(t)^{\prime}(D(t))=\left(\beta_{1} \wedge D 2(t)(D(t)),\right. \\
& E 1(t)^{\prime}(E(t))=\left(\beta_{1} \wedge E 1(t)(E(t)),\right. \\
& D 2(t)^{\prime}(D(t))=\left(\beta_{2} \wedge D 2(t)(D(t)),\right. \\
& E 1(t)^{\prime}(E(t))=\left(\beta_{2} \wedge E 1(t)(E(t)),\right. \\
& D 1(t)^{\prime}(D(t))=\left(\beta_{3} \wedge D 1(t)(D(t)),\right. \\
& E 2(t)^{\prime}(E(t))=\left(\beta_{3} \wedge E 2(t)(E(t)),\right. \\
& D 3(t)^{\prime}(D(t))=\left(\beta_{4} \wedge D 3(t)(D(t)),\right. \\
& E 3(t)^{\prime}(E(t))=\left(\beta_{4} \wedge E 3(t)(E(t)),\right. \\
& D 2(t)^{\prime}(D(t))=\left(\beta_{5} \wedge D 2(t)(D(t)),\right. \\
& E 2(t)^{\prime}(E(t))=\left(\beta_{5} \wedge E 2(t)(E(t)),\right. \\
& \mu_{\Sigma}(D(t))=\left(\beta _ { 1 } \wedge D 2 ( t ) ( D ( t ) ) \vee \left(\beta _ { 2 } \wedge D 2 ( t ) ( D ( t ) ) \vee \left(\beta_{3} \wedge D 1(t)(D(t)) \vee\right.\right.\right. \\
& \vee\left(\beta _ { 4 } \wedge D 3 ( t ) ( D ( t ) ) \vee \left(\beta_{5} \wedge D 2(t)(D(t)),\right.\right.
\end{aligned}
$$




$$
\begin{gathered}
\mu_{\Sigma}(E(t))=\left(\beta _ { 1 } \wedge E 1 ( t ) ( E ( t ) ) \vee \left(\beta _ { 2 } \wedge E 1 ( t ) ( E ( t ) ) \vee \left(\beta_{3} \wedge E 2(t)(E(t)) \vee\right.\right.\right. \\
\vee\left(\beta _ { 4 } \wedge E 3 ( t ) ( E ( t ) ) \vee \left(\beta_{5} \wedge E 2(t)(E(t)),\right.\right. \\
D(t)_{0}=\frac{\int_{\Omega} D(t) \mu_{\Sigma}(D(t)) d D(t)}{\int_{\Omega} \mu_{\Sigma}(D(t)) d D(t)}, \\
E(t)_{0}=\frac{\int_{\Omega} E(t) \mu_{\Sigma}(E(t)) d E(t)}{\int_{\Omega} \mu_{\Sigma}(E(t)) d E(t)} .
\end{gathered}
$$

Таким чином, інтелектуальний алгоритм керування для енергоефективного вирощування ентомофагів складається 3:

- контролю параметрів техноценозу (температури та відносної вологості повітря боксу для розведення комах);

- контролю кількості та якості ентомологічної продукції;

- контролю загальних витрат на інокуляцію поживного середовища яйцями комахи-хазяїна;

- контролю загальних витрат електроенергії;

- створення експертних систем нечіткого висновку для оцінки прибутку виробництва ентомокультур;

- визначення таких параметрів процесів вирощування, за якими прибуток досягатиме максимального значення за умови мінімізації енерговитрат.

Висновки і перспективи досліджень. Розроблено інтелектуальний алгоритм керування для енергоефективного вирощування ентомофагів, який на основі теорії нечіткої логіки, із використанням результатів експериментальних досліджень, з урахуванням збурення в умовах неповної вхідної інформації дає змогу визначити такі параметри вирощування ентомокультур, що забезпечують максимізацію прибутку виробництва за умови мінімізації енерговитрат.

\section{Список використаних джерел}

[1] Сухонос М. К. Разработка системы оценки энергоэффективности энергоинфраструктуры предприятия. Энергосбережение. Энергетика. Энергоаудит. 2011. № 4. С. 16 - 21.

[2] Севастьянов Р. В., Калініна Я. Ю. Енергоефективність промислових підприємств України та бар'єри 3 їі впровадження. Економічний вісник Запорізької держсвної інженерної академії. 2014. Вип. 7. С. 144-154.

[3] ДСТУ 2155-93. Енергозбереження. Методи визначення економічної ефективності заходів по енергозбереженню. Чинний від 01.01.95. К. : Держстандарт України.

[4] Lysenko V. P., Koval V. V., Nakonechna K.V., Kalian D.O. Modern information technologies in the control systems for complex biotechnical objects of agricultural appointment. Information and Telecommunication Sciences . 2017. V. 9. N. 2. P. 38-43.

[5] Djatkov D., Effenberger M., Martinov M.. Method for assessing and improving the efficiency of agricultural biogas plants based on fuzzy logic and expert systems. Applied Energy . 2014. 134. Р. 163-175.

[6] Заєць Н. А., Дудник А. О., Якименко І. Ю. Експериментально-статистичне дослідження теплиці як об’єкта керування з метою підвищення ресурсоефективності виробництва. Енергетика $і$ автоматика. 2017. № 4. URL: http://journals.nubip.edu.ua/index.php/Energiya/article/view/9538/8533

[7] Lysenko V., Chernova I. Information Provision for Automated Production of Entomophages: 2017 4th International Scientific-Practical Conference Problems of Infocommunications Science and Technology (PIC S\&T). Kharkiv, 2017. P. 142-145. DOI: 10.1109/INFOCOMMST.2017.8246368

[8] Зольников В. А. Подходы к описанию иерархических систем: матеріали Міжнар. наук.-техн. конф. «Сучасні методи, інформаційне, програмне та технічне забезпечення систем управління організаційно-технічними та технологічними комплексами», 27 листопада 2014 p. К: НУХT, 2014 р. С. 136-137. URL: http://nuft.edu.ua/page/view/konferentsii

[9] Шалабанов А. К., Роганов Д. А. Эконометрика. Учебно-методическое пособие. Казань: Академия управления «ТИСБИ», 2008. 203 с.

[10] Дьяконов В., Круглов В. Математические пакеты расширения MATLAB. Специальный справочник. СанктПетербург: Питер, 2001. 488 с.

\section{References}

[1] Suhonos M. (2011). Razrabotka sistemy ocenki jenergojeffektivnosti jenergoinfrastruktury predprijatija [Development of a system for assessing the energy efficiency of an enterprise's energy infrastructure]. Jenergosberezhenie. Jenergetika. Jenergoaudit. N. 4. P. 16 - 21. [in Russian].

[2] Sevast'janov R., Kalinina Ja. (2014). Energoefektyvnist' promyslovyh pidpryjemstv Ukrai'ny ta bar'jery z i'i' vprovadzhennja [Energy efficiency of Ukrainian industrial enterprises and barriers to its implementation]. Ekonomichnyj visnyk Zaporiz'koi' derzhavnoi' inzhenernoi' akademii'. V. 7. P. 144-154. [in Ukraine]. 
[3] DSTU 2155-93. Energozberezhennja. Metody vyznachennja ekonomichnoi' efektyvnosti zahodiv po energozberezhennju [DSTU 2155-93. Energy saving. Methods of determining the economic efficiency of energy saving measures]. Chynnyj vid 01.01.95. K. : Derzhstandart Ukrai'ny. [in Ukraine].

[4] Lysenko V., Koval V., Nakonechna K., Kalian D. (2017). Modern information technologies in the control systems for complex biotechnical objects of agricultural appointment. Information and Telecommunication Sciences. V. 9. N. 2. P. 38-43.

[5] Djatkov D., Effenberger M., Martinov M. (2014). Method for assessing and improving the efficiency of agricultural biogas plants based on fuzzy logic and expert systems. Applied Energy. N. 134. P. 163-175.

[6] Zajec' N., Dudnyk A., Jakymenko I. (2017). Eksperymental'no-statystychne doslidzhennja teplyci jak ob'jekta keruvannja z metoju pidvyshhennja resursoefektyvnosti vyrobnyctva [Experimental-statistical study of greenhouses as a control object in order to increase resource efficiency of production]. Energetyka i avtomatyka. N.4. URL: http://journals.nubip.edu.ua/index.php/Energiya/article/view/9538/8533 [in Ukraine].

[7] Lysenko V., Chernova I. Information Provision for Automated Production of Entomophages: 2017 4th International Scientific-Practical Conference Problems of Infocommunications Science and Technology (PIC S\&T). Kharkiv, 2017. P. 142-145. DOI: 10.1109/INFOCOMMST.2017.8246368

[8] Zol'nikov V. (2014). Podhody k opisaniju ierarhicheskih system [Approaches to the description of hierarchical systems]: materialy Mizhnar. nauk.-tehn. konf. «Suchasni metody, informacijne, programne ta tehnichne zabezpechennja system upravlinnja organizacijno-tehnichnymy ta tehnologichnymy kompleksamy», 27 lystopada 2014 r. K, NUHT. P. 136-137. URL: http://nuft.edu.ua/page/view/konferentsii [in Ukraine].

[9] Shalabanov A., Roganov D. (2008). Jekonometrika. Uchebno-metodicheskoe posobie. [Econometrics. Teaching guide]. Kazan': Akademija upravlenija «TISBI». 488 p. [in Russian].

[10] D'jakonov V., Kruglov V. (2001). Matematicheskie pakety rasshirenija MATLAB. Special'nyj spravochnik [MATLAB Math Expansion Packs. Special Handbook]. Sankt-Peterburg: Piter. 488 p. [in Russian]. 